\title{
AN EXAMINATION OF US FDI INTO MEXICO AND ITS \\ RELATION TO NAFTA: Understanding the Effects of Environmental \\ Regulation and the Factor Endowments that Affect the Location Decision
}

\author{
Elizabeth T. Cole \\ Prescott C. Ensign
}

\begin{abstract}
This article examines the impact of the NAFTA signing on US foreign direct investment into Mexico with respect to environmental expenditures and factors including capital, technology, and both skilled and unskilled labor. Our results demonstrate, somewhat counterintuitively, a trend of US foreign direct investment into Mexico in industries characterized as lower polluting. Further, our analysis is unable to detect firm movement to Mexico for either specifically high or low technology workers.
\end{abstract}

Earlier versions of this article were presented at the Canadian Economics Association and the Academy of International Business meetings. We thank participants for their comments. We are also grateful for suggestions provided by Rafael Montoya Ortega. We are indebted to the editor of this journal, Antonio Rodriguez, and the anonymous referees for providing direction in shaping this article. The second author benefited from a research grant from the California State University and received support as a Fulbright Scholar from the Foundation for Educational Exchange between Canada and the United States, the Institute of International Education, and the J. M. Smucker Company.

Cole, E.T. and Ensign, P.C. (2005) An Examination of US FDI into Mexico and Its Relation to NAFTA: Toward a Balanced Understanding of the Effects of Environmental Regulation and the Factor Endowments that Affect the Location Decision. International Trade Journal. 19(1): 1-30.

This is an electronic version of an article published in International Trade Journal. 19(1): 1-30. International Trade Journal is available online at:

http://www.informaworld.com/smpp/title content=t713772442. 
The MIT Economics Department has now solved the riddle of world economic crisis. It turns out that if you add up last year's reported imports and exports for all countries in the world, world imports exceeded world exports by more than one hundred billion dollars. You know what that means. It means that we are running a huge global deficit in our interplanetary trade. So Ross Perot has it wrong. That great sucking sound isn't coming from Mexico-it's coming from outer space. Space aliens are stealing American jobs.

—Paul Krugman

\section{INTRODUCTION}

The North American Free Trade Agreement (NAFTA) is based on the premise that free trade and investment between countries allow for greater efficiency in the allocation of resources. This in turn results in greater wealth for all parties involved. Opponents of NAFTA claim that free trade and investment with Mexico will undermine Canadian and US standards of conduct because Mexico will subsidize its productive capital — and subsequently exports — via lower social standards. ${ }^{1}$ Proponents of NAFTA claim that increased trade with and investment in Mexico will serve as an incentive and actually improve the Mexican

\footnotetext{
${ }^{1}$ Or, what are effectively lower standards due to lax enforcement.
} 
standard of living, thus increasing their ability to match the social values of the more northerly North Americans.

This article examines the reasons why US-based multinational enterprises (MNEs) locate in - or relocate to-Mexico during the NAFTA era, that is, 1989 through 1993 (before and after its 1992 signing). The primary thrust of the article centers on exploring:

1. whether foreign direct investment (FDI) into Mexico is associated with the avoidance of high environmental compliance costs

2. whether a highly skilled, undervalued Mexican workforce is responsible for the influx of foreign controlled operations

3. or to both of the aforementioned factors

The results of this study show that US FDI into Mexico is moving toward industries characterized as lower polluting. In fact, restrictive Mexican investment policies of the 1980s may have limited earlier investment in Mexico to those industries where environmental damage is typically higher. That is, based on indicators of Mexican comparative advantage, US MNEs might have previously selected more environmentally benign industries given their druthers.

The present study is not able to determine whether movement to Mexico is for either high or low technology workers. This result tentatively supports the proposition that all workers in Mexico, skilled or unskilled, have roughly equal comparative advantage over US workers in wage and productivity tradeoffs. NAFTA advocates argue that FDI enters Mexico to utilize unskilled labor because productivity per worker hour is not as important for unskilled labor as it is for skilled labor. They contend that the tradeoff between wages and productivity will not make 
it worthwhile to move skilled jobs to Mexico because wage savings will not offset the decrease in productivity. Labor argues that skilled jobs will move to Mexico because savings will offset the lower productivity. The results of our research suggest that FDI selects Mexico to obtain wage savings for skilled as much as for unskilled labor, because competitive advantage exists for both factors.

The remainder of this article proceeds as follows: section two discusses free trade and NAFTA issues; section three summarizes the relevant FDI issues as they apply to Mexico; section four describes methods, statistical tests, and results; and the final section presents our summary and conclusions.

\section{FREE TRADE AND TRADE AGREEMENTS}

A major tenet of trade theory is that a given country will produce and export the goods where its factor endowments (land, labor, natural resources, and capital) for the production processes are greater than the factor endowments of other countries. Historically, nations gain factor-based comparative advantage in industries that utilize abundant factor endowments. ${ }^{2}$ Efficient use of relative factor endowments and subsequent trade increases the welfare of the parties involved. A country will, ceteris paribus, continue to produce goods and trade any excess of these goods to other countries as long as its advantage in relative factor endowments exceeds the costs of trade.

An advantageous position in factor endowments may be the result of any number of elements, ranging from geographical attributes to inexplicable competences. Penrose (1995) pointed out that it is a firm's resources - physical, financial, tangible,

${ }^{2}$ This view of comparative advantage is based on all nations possessing equivalent technology. 
and intangible - that provide the firm with advantage. Labor endowments include both the size and quality of the labor force. Natural resource endowments can range from fertility of the soil, to mineral deposits, to energy sources (Baldwin, 1971). Finally, environmental subsidies (through minimal regulation or lack of enforcement) have been considered important factors of production; however, empirical tests have thus far been unable to isolate this effect.

The last factor endowments to consider are investment capital and technology — though the latter may be embodied in labor. Without the proper technology and investment capital, it is not always possible to fully utilize other resources and factor endowments. An investing firm has to overcome disadvantages of not being native. Special properties essential for nonindigenous firms to succeed may come through coordination and efficient synchronization of operations. For investing firms, FDI is used as a way to obtain location advantages, for example, secure market access through proximity, avoid trade barriers, or take advantage of relative factor endowments. Ownership or resource-based advantages may be context-dependent attributes linked to knowledge/learning and even irreducible to explanation. Internalization advantages can be arrived at through transaction cost analysis and are primarily the result of market failure. For the receiving country, FDI is a vessel for the transfer of capital and knowledge. Because of its allure, technology transfer is frequently dangled in front of prospective host countries.

FDI is a vital path for firms from developed countries where profitable investment options are dwindling and overall profits may be flat. FDI allows firms to: find avenues for expansion where none/few profitable outlets exist domestically; seek options with greater profitability (extract higher rents); and diversify as a valid means of smoothing/stabilizing profits. In general, 
developing countries have a greater need for an influx of capital and knowledge so that they can compete in world markets. For both the investor and the host, FDI spurs the efficient use of relative factor endowments.

Recognizing the importance of free trade, the international community has made a number of efforts to eliminate trade restrictions. Most notably, GATT has stimulated/enforced freer trade between countries. In addition to GATT a number of countries have entered into free trade areas or blocs in order to take further advantage of the efficiencies provided through free trade and mobility of investment. The US has established free trade areas with Israel, Canada, and most recently with Mexico. Even now, attention turns toward Chile and other countries. US direct investment into Mexico during the NAFTA era remains the primary focus of this paper though findings may_-with caution—-be carried to additional contexts.

Almost all areas of trade and investment are covered in the NAFTA agreement; except for certain energy sectors where there are restrictions for national security reasons. The general provisions of NAFTA are written to promote fair competition, protect intellectual property, and maintain non-discriminatory standards for quality, health and safety. Even arbitration provisions are written into the document to permit the settlement of disputes. Economic disparity between Mexico and its neighbors to the North have caused concern in a number of areas, the most prominent of these issues will be discussed in the following section.

\section{FOREIGN DIRECT INVESTMENT AND MEXICO}

Prior studies have identified causal factors for FDI location decisions. Such factors include: proximity to export country, labor availability as well as productivity, political stability, and 
infrastructure. Mexico is physically close to the US, but far from being similar to the US. Labor in Mexico is sweepingly characterized as cheaper and more plentiful. However, lower productivity in Mexico may offset what would otherwise be a strong factor advantage in labor. Mexico's infrastructure is generally much less developed. ${ }^{3}$

Given Mexico's apparent weakness in several factor endowments, why would US firms invest in Mexico? One possibility is the availability of cheap labor. Other reasons may lie in an array of unmeasured tangible and intangible endowments. Capital endowments include supply side factors but also incentives offered by governmental bodies. Some argue that the opportunity to indiscriminately damage the environment without penalty is such an incentive.

Though our search for adequate supply side reasons to invest in Mexico leaves us short, the demand side offers strong support for increased FDI (Globerman, 1993). Some time ago, Wright (1971: 3) observed that, with respect to Mexico, inducements to FDI "exist there to an unusually high degree." After a period of decline in the 1980s, it once again appears that market pull factors in Mexico are as significant as in prior years. The process of further opening the economy - apertura - to foreign competition and investment, even to the detriment of government control started with Mexico's accession to GATT in 1986. In the US, facing an ever diminishing domestic demand for goods and services, in which production capacity is becoming ever larger, outpacing a shrinking purchasing power, it seems logical for US enterprises to look South to a growing base of unsatiated increasingly affluent prospective customers.

\footnotetext{
${ }^{3}$ Infrastructure is not addressed directly in this study, though it may be partially captured in the education, training, and skills of the labor force.
} 
"Two sources of evidence can be used to investigate the sensitivity of firms' investment patterns to environmental regulations: changes in direct foreign investment and siting decisions for do mestic plants" (Jaffe, Peterson, Portney, and Stavins, 1995: 146). Studies (cf. Friedman, Gerlowski, and Silberman, 1992; Levinson, 1996) have examined the effects of regional environmental policies on locational decisions within the US. Such studies are relevant because selection among domestic site choices parallels the location decisions made under the growing atmosphere of free trade and investment. The main difference between US domestic and Mexican site selection is that Mexico has infrastructure disadvantages and possibly a labor disparity with the US. Earlier studies had not found significant location decision factors, but were unable to rule out the possibility that such inducements exist.

Given the previous analysis it is not difficult to understand why FDI and free trade should be a political "hot box" with compelling arguments on both sides. From a purely theoretical vantage, free trade and investment should benefit all- "freer trade among the United States, Canada, and Mexico will energize all three economies" (Naisbitt, 1994: 244). However, more detailed economic, social, and political arguments suggest that a liberalizing economic environment may not always be welcome or beneficial. Our position is that the most valid arguments against NAFTA are more subtle and possibly more important. For instance, consider the counterintuitive claim that environmental regulation is not only benign, but if properly formulated, can enhance competitiveness and lead to innovation (Porter and van der Linde, 1995). Or if much time and effort is concentrated on examining labor unions only to learn that this is a moot point; Friedman (1962: 123) found that "even the strong and powerful unions have only a limited effect on the wage structure." 


\section{Side Agreements}

The primary concerns, addressed at least to some degree in the NAFTA side agreements, are environmental and labor-related. Environmentalists argue that MNEs will be liberated and move to Mexico - the pollution haven. Labor advocates argue that MNEs will relocate in Mexico to take advantage of artificially concocted low wages caused by the quasi-governmental labor union.

The labor side agreements specifically reinforce labor standards and safety, call for the enforcement of labor protection laws in Mexico, and allow tariff reinstatement if a country experiences damaging job losses in a specific industry. It is important to highlight the link between rising environmental regulation and labor. Jaffe, Peterson, Portney, and Stavins (1995) foretold that if those US industries most affected by environmental regulation employ less educated workers, then this portion of the labor force will be particularly hard hit by the transition, where "short run" social adjustment costs could last for years or decades. In anticipation, the US-instituted budgetary provisions for dealing with temporary worker dislocation. There is, however, some counter-indication that this effort to deal with the unemployed and underemployed will be nominal — the Trade Adjustment Assistance program declined during the 1980s and may be unable to meet the majority of needs (Ensign, 2003).

The environmental side agreements deal with cleaning the contaminated US-Mexican border, protection of wildlife, and mutual development of environmental standards. Post (1991) provided an account indicating that the Mexican environmental protection agency is taking action to improve air quality for the world's largest urban population-Mexico City. "As a collective good, environmental protection is a difficult commodity to value because it is available to all whether or not they pay for it" 
(Tucker, 1995: 52). It is the southern hemisphere, with ill-defined property rights on environmental resources, trading with the northern region with well-defined property rights that transmits and enlarges the problem of the commons. In essence, the "North overconsumes underpriced resource-intensive products imported from the South" (Chichilnisky, 1994: 851).

However, even with these side agreements the debate over the impact of NAFTA has continued. The primary arguments on both sides of the discussion for both environmental and labor issues are discussed and considered in our empirical analysis.

\section{Environmental Arguments}

The environment has become viewed as a limited, non-renewable resource. Where once the land could cure itself from almost any damage that humans could inflict, it has become evident that this is no longer the case. Roosevelt (1934: 205) stated that the growth of the nation "has been due to the rapid development, and, alas! that it should be said, to the rapid destruction, of our natural resources."

Mechanization of agriculture in Mexico has also been criticized. High-tech farmsagromaquilas - have been linked to deleterious effects on the natural environment.

Environmentalists believe that high costs of environmental compliance in the US and Canada, which keep environmental damage low in northern North America relative to the rest of the Americas, will cause firms to move to Mexico as obstructions to trade and investment are reduced. They point to the Maquiladora region - already replete with ecological damage from US plants - as proof of their arguments. Birdsall and Wheeler (1992) recorded evidence that pollution intensity in developing countries rises after industrialized countries move to institute and enforce environmentally protective legislation domestically. 
Clearly there exist direct ecological links among countries and environmental repercussions from economic development are real. However, assessments, diagnoses, and actions specified vary widely. NAFTA supporters do not accept many of the preceding arguments, envisioning instead a much different scenario unfolding. They contend that what the Mexican government has done and promises to do will prohibit further environmental abuses of the magnitude seen in the Maquiladora region. Economists typically argue that a rise in national income through economic integration increases demand for environmental quality, making new investment in pollution abatement affordable, and thereby generating government revenue for the enforcement of environmental regulations (Copeland and Taylor, 1995). This may be countered with the equally rational position that trade may "in crease world pollution by raising the scale of economic activity and by providing added incentives for polluting industries to locate in countries with low environmental standards" (Copeland and Taylor, 1995: 716).

While theory provides no definitive solution, some consensus has been reached in the literature. A Kuznets curve (inverted U-shape) exists for many pollutants (Harvey and Rothe, 1995; Seldon and Song, 1994). This shows that both low and high economic development are characterized by low pollution while industrial progress in the intermediary is associated with high levels of pollution and environmental degradation. Hettige, Lucas, and Wheeler (1992: 479) found an inverse U-shaped pattern for intensity per unit of GDP, however "results suggest that the pollution intensity of manufacturing [per unit of] output rises steadily with income, at most tapering off somewhat at very high incomes." The argument gains further complexity if the imported industrial equipment is newer (less polluting) than that currently available in the developing country. Krugman (1993) held that 
benefits will accrue to geographical relocation—essentially, increased dispersion—of Mexican industry.

The US Congressional Research Service (CRS) (1992: 164) stated that four characteristics must be present to motivate an international move or redirect future investment to Mexico:

1) Environmental compliance in the industry is a significant portion of total operating costs.

2) Existing trade barriers must be significant.

3) Costs of relocating or creating new capacity must not overwhelm compliance cost gains.

4) Differences in a firm's environmental compliance costs must be sufficiently different among the countries to warrant location changes.

CRS researchers hold that only those industries with both high abatement costs as a percentage of value added and high Mexican trade barriers would have reason to move to Mexico. They concluded that none of the industries that fit this criterion would be likely to move to Mexico because they were highly capital intensive, and excess world capacity already generally existed.

If the CRS study is correct, there is no reason to believe that firms see Mexico as a refuge from pollution-related expenses. However, methods employed in their study are questionable. They failed to use a systematic statistical analysis. They assumed that the only barriers to consider were trade restrictions. They did not explicitly examine the amount of new capital expenditures. Further, they considered only the subset of environmental expenditures represented by current operating costs, not the larger expenditures - either present investment or future outlays - for pollution abatement.

To determine if the conclusions of the CRS study were correct—in spite of its weaknesses — we systematically retest their 
assumptions in this article. To correct for the use of only one type of environmental expenditure, we aggregated both the yearly operating and capital expenditures. We examined sequential years of data to determine, as NAFTA came to fruition during the period 1989 through 1993, the nature and magnitude of US FDI into Mexico.

\section{Labor Arguments}

Unions registered with the government of Mexico receive preferential treatment and protection from opposition or competing unions. In return, those unions work with the Mexican government in helping to control wage increases in inflationary periods (US Congress, 1992). The Mexican industrial policy of el pacto, or national wage and price control, has its sights on increased productivity. Representatives of government, business, and labor have settled on a National Productivity Accord as well as a Pact on Stability, Competitiveness, and Employment (Cohen, 1993).

While it is undeniable that immobility of labor may be a stimulus for FDI, US labor protectionists insist that corporations moving to Mexico will be exploiting Mexican workers and taking jobs from the truly protected US workers. Wood (1994) indicated that it is the unskilled worker in the developed country who is most vulnerable to freer trade. A more altruistic position points to humanitarian objections, citing studies that find US MNEs located in the Maquiladora region commit abuses on Mexican workers, particularly women and children (Ensign, 2003). Reconciling differences among nations of disparate development levels requires that national patterns of industrial specialization be reconfigured (Campbell, 1994). Some scholars characterize the expected adjustment as "upward harmonization" while others envision the future as bringing "downward harmonization." A priori, 
there are reasons to both support and refute these two possibilities. Labor protectionists argue that free trade with Mexico will perpetuate labor abuses in Mexico. Not only will a travesty of human rights violations continue, but this will force unfair competition that may reduce labor standards in the US.

Proponents of NAFTA point out that labor costs are no longer a sizable portion of manufacturing costs in most industries. They show that in high technology industries — which have the jobs that the US would like to keep-labor costs do not offset the other costs associated with operations in Mexico, such as transportation. For instance, the following comparison was compiled by the US Congressional Office of Technology Assessment (1992). Estimates are based on industry interviews. Data show that even with a significant reduction in Mexican wages, it is still less expensive to manufacture products in the US (see Table I for an example of the automobile industry).

Table I Automobile Production Costs in the US and Mexico

\begin{tabular}{lcr}
\hline & United States & Mexico \\
\hline Labor & $\$ 700$ & $\$ 140$ \\
Parts, components, etc. & 7,750 & 8,000 \\
Component shipping cost & 75 & 600 \\
Finished vehicle shipping & 225 & 400 \\
Inventory costs & 20 & 40 \\
Total & 8,770 & 9,180 \\
\hline
\end{tabular}

Source: US Congressional Office of Technology Assessment 1992.

Mexican workers' average education level is such that technology intensive industries must use reduced technology in order to produce products while Mexico's new technology in emerging industries; sophisticated capabilities, improving quality, and 
productivity rates are converging on those of the US (Martin, 1994). The Mexican government is a promoter and participant in la modernidad - a program of increasing industrial efficiency. Reports by well-respected researchers and economists support all sides of the NAFTA controversy. It is "difficult and probably foolhardy to try to draw any concrete conclusions concerning the aspect of NAFTA on US jobs" (Martin, 1994: 247).

In order to examine the impact of the signing of NAFTA in 1992, we test whether Mexican wages as a percentage of US wages are a factor in the firm's decision to move to Mexico. Unlike most studies that look at labor in aggregate, we explore the issue of skilled versus unskilled labor. By measuring technology as the value added per employee, we also test whether or not it is low technology firms that are moving to Mexico.

\section{METHODS AND RESULTS}

The first model is used to identify factors that determine US FDI into Mexico. Linear regression is employed to model the factors. Foreign direct investment is the dependent variable as measured by the US Department of Commerce. The balance of trade between the US and Mexico is used to identify the industries where Mexico has relative factor endowments in excess

of the US. Return on investment is utilized as a proxy for growth and investment opportunity in that industry. Year is an explanatory variable used to proxy for temporal change covering the pre and post-NAFTA signing period.

Model:

$$
F D I_{i t}=\beta_{0}+\beta_{1} \text { Balance of } \operatorname{Trade}_{i t}+\beta_{2} R O I_{i t}+\beta_{3} \mathrm{Year}_{i t}+\varepsilon
$$


Where:

$\mathrm{FDI}=\mathrm{US}$ foreign direct investment in Mexico

Balance of Trade $=$ US-Mexico trade balance

$\mathrm{ROI}=$ return on US FDI in Mexico

Year $=1991$ to 1993 (18 observations per year using 3-digit SIC codes with sufficient data)

Hypothesis 1: Balance of Trade is positively related to US FDI in Mexico

Hypothesis 2: ROI is positively related to US FDI in Mexico

Hypothesis 3: Year is positively related to US FDI in Mexico

Trade and investment are intertwined topics and generally found to be related. That is, a major change in one will have a significant impact on the other. In keeping with previous research, our model indicates that there is a relationship between the balance of trade and FDI. Both the year and the international return on investment had a positive relationship with FDI, however neither coefficient proved statistically significant. Table II provides details on the relationships.

Table II Determinants of US FDI into Mexico

Model: $F=3.176(0.032)$

Adjusted $R^{2}=0.1097$

\begin{tabular}{lcc}
\hline Variable & T value & P value (one tailed) \\
\hline Balance of Trade & 2.354 & 0.0226 \\
ROI & 1.265 & 0.1054 \\
Group (by SIC code) & 0.295 & 0.3848 \\
\hline
\end{tabular}


To determine more definitively the changing relationship between FDI and time, the regression model was repeated for each year, using the most significant variable, balance of trade, as the sole explanatory variable. None of the models prove to be statistically significant, however the trend indicates that balance of trade appears to be converging on FDI $\left(1991 R^{2}=\right.$ $0.01, p=0.18 ; 1992 R^{2}=0.027, p=0.11 ; 1993 R^{2}=0.113, p=0.06$ ).

From the preceding analysis we infer that US foreign direct investment in Mexico is moving toward industries where Mexico has a trade surplus with the United States. After relaxation of FDI restrictions in the late 1980s, US foreign direct investment in Mexico moved toward areas where a comparative advantage exists as measured by the trade balance.

The next step in the analysis is to determine exactly what factors cause Mexico's competitive advantage. The areas of greatest concern in this investigation are with respect to labor and environmental subsidies. To test hypotheses in these areas, we test to see if the balance of trade between the US and Mexico was affected by pollution expenditures or by the technology embodied in the workers. For pollution expenditures, both capital and operating expenditures as measured by the US Department of Commerce were used.

Model:

$$
\begin{aligned}
{\text { Balance of } \text { Trade }_{i t}=} & \beta_{0}+\beta_{1} \text { Pollution Expenditures }_{i t} \\
& +\beta_{2} \text { Value Added Manufacturing } \\
& +\beta_{3} \text { New Capital } \\
& +\beta_{4} \text { Year }_{i t}+\varepsilon
\end{aligned}
$$

Where:

Balance of Trade $=$ US-Mexico trade balance as a proxy for Mexican comparative advantage 
Pollution Expenditures $=$ Pollution-related expenditures for US firms

Value Added Manufacturing $=$ A proxy for technological expertise

New Capital $=$ New capital expenditures by US firms

Year $=1991-1992$ for Balance and Pollution Expenditures, 1990-1991 for New Capital and Value Added Manufacturing and 0 or 1 for year

Hypothesis 4: Pollution Expenditures are negatively related to Balance of Trade

Hypothesis 5: Value Added Manufacturing is positively related to Balance of Trade

Hypothesis 6: New Capital is positively related to Balance of Trade

Hypothesis 7: Year is positively related to Balance of Trade

We found that while the overall model is significant, the only variable that is significant is the Pollution Expenditures variable. The coefficient is negative indicating that industries with low pollution expenditures move to Mexico. Table III shows the details of the regression.

Additional tests were conducted to determine if the results were robust to misspecification errors. It was found that when the variable Value Added Manufacturing is removed, the model and all other variables become more significant (model $p=0.0198, R^{2}=$ 0.1114), indicating that there may be some negative correlation between Value Added Manufacturing and the other variables. Additionally, when New Capital is removed from the initial equation, the new model and Pollution Expenditures become more significant than the starting model ( $p=0.0313, R^{2}=0.09$ ). When Pollution Expenditures is used as the sole dependent variable, the model has a $p$-value of 0.0044 and an $R^{2}$ 
Table III Determinants of Mexico's advantage

(as reflected in US-Mexico balance of trade)

\begin{tabular}{lrc} 
Model: $F=2.711(0.0388)$ & & \\
Adjusted $R^{2}=0.1009$ & & \\
\hline Variable & T value & P value (one tailed*) \\
\hline Pollution Expenditures & -2.310 & 0.012 \\
Value Added Manufacturing & -0.565 & 0.5741 \\
New Capital Expenditures & 1.148 & 0.127 \\
Year & -0.541 & 0.5907 \\
\hline
\end{tabular}

*Two tailed for Value Added Manufacturing.

of 0.1129 indicating that pollution related expenditures for US firms plays a substantive role in explaining differences in factor endowments between the US and Mexico.

Finally, when Value Added Manufacturing is deflated by worker hours, to determine the value added manufacturing per worker hour, there is a significant negative relationship ( $p=$ 0.035 ) between value added manufacturing per worker hour and trade balance. This final result indicates that low technology per worker hour industries do indeed locate in—or perhaps relocate to-Mexico.

To examine the trend of US foreign direct investment in Mexico, we test to determine if the overall growth in US FDI was associated with any of the determinants tested above.

Model:

$$
\begin{aligned}
& \text { Growth }_{i t}=\beta_{0}+\beta_{1} \text { Year }_{i t} \\
&+\beta_{2} \text { Value Added/Worker Hour }_{i t} \\
&+\beta_{3} \text { New Capital } \\
& i t \\
& \\
&+\beta_{4} \text { Pollution Expenditures }_{i t}+\varepsilon
\end{aligned}
$$


Where:

Growth $=$ Growth in US foreign direct investment in Mexico from 1989 through 1993

Pollution Expenditures $=$ Pollution-related expenditures for US firms.

Value Added/Worker Hour = Value added by manufacturing per worker hour (as a proxy for technological expertise).

New Capital $=$ New capital expenditures by US firms

Year = 1991-1992 for Balance and Pollution Expenditures, 1990-1991 for New Capital and Value Added Manufacturing, and 0 or 1 for Year

Hypothesis 8: Pollution Expenditures are negatively related to Growth Hypothesis 9: Value Added/Worker Hour is positively related to Growth Hypothesis 10: New Capital is positively related to investment in Mexico Hypothesis 11: Year is positively related to Balance

From this model, we find that both the model and pollution expenditures remain significant. Both the year variable and new capital expenditures have signs as hypothesized, however only new capital expenditures is weakly significant. Results are detailed in Table IV

All results indicate that movement of US firms to Mexico occurs in industries where the pollution expenditures are lower than average with no particular emphasis on the technological 
Table IV Determinants of the Growth of US FD1 in Mexico

\begin{tabular}{lcc}
\hline $\begin{array}{l}\text { Model: } F=3.847(0.0377) \\
\text { Adjusted } R^{2}=0.1574\end{array}$ & & \\
\hline Variable & T value & P value (one tailed*) \\
\hline Pollution Expenditures & -3.213 & 0.0120 \\
Value Added/Worker Hour & -0.121 & 0.5741 \\
New Capital Expenditures & 1.428 & 0.0600 \\
Year & 0.100 & 0.4990 \\
\hline
\end{tabular}

*Two tailed for Pollution Expenditures and Value Added/Worker Hour.

needs for employees. However, while the value added for production, and the value added per employee hour are fairly good proxies for the technological capabilities and needs of industries moving to Mexico, pollution expenditures may not be a good proxy for industry pollution.

Low costs of environmental compliance do not necessarily indicate low pollution industries. Pollution expenditures are measured by the Bureau of Census as the amount of pollution expenditures, by year, that US firms actually spend. Therefore, the negative relationship between pollution expenditures and competitive advantage and US FDI in Mexico could be indicating that industries with low pollution expenditures have moved to Mexico. However, it could also indicate that industries have moved to Mexico in sufficient quantity to statistically alter the industry average; that is, are able to avoid enough pollution expenditures to make them appear as low pollution expenditure industries. Finally, it is conceivable that low pollution expenditure industries might be locating in/relocating to Mexico for reasons that are simply not captured by the categories used in our analysis.

To examine this area further, we examine separately each of the industries where Mexico had a competitive advantage vis-à-vis 
the US as measured by the balance of trade. These industries are listed by the magnitude of their positive trade balance in Table $\mathrm{V}$.

Next, those industries in Mexico that had positive trade balances with the US were compared to pre-NAFTA era (1988) pollution expenditures as a percentage of total industry value added. Industries where pollution expenditures were greater than two percent of total value added were included; their rankings by percentage of value added, are shown in Table V.

While there appears to be a fair representation of industries with high pollution abatement costs as a percentage of value added in Mexico's top exporting industries, this does not appear to be the driving force. For instance, none of the top three industries exporting from Mexico is a high pollution industry. Additionally, the other industries that are represented appear to be industries where the competitive advantage lies in the natural resources of the country, such as mineral deposits.

Table V Mexico's Most Competitive Industries and Their Pollution Levels

\begin{tabular}{cclcc}
\hline $\begin{array}{c}\text { DI } \\
\text { Class }\end{array}$ & $\begin{array}{c}\text { Balance } \\
\text { of Trade } \\
\text { (\$S millions) }\end{array}$ & Industry & $\begin{array}{c}\text { 4-digit } \\
\text { SIC code }\end{array}$ & $\begin{array}{c}\text { Pollution } \\
\text { Ranking }\end{array}$ \\
\hline 366 & $1,548,511$ & Radio, TV, and Communication & & \\
203 & $1,261,733$ & Preserved Fruits and Vegetables \\
371 & 964,669 & Motor Vehicles and Equipment & & \\
208 & 526,353 & Beverages & 2083 & 34 \\
230 & 431,924 & Apparel and Other Textile & 3295 & 54 \\
329 & 167,070 & Mineral & 3241 & 6 \\
& $\quad$ Cement & 3274 & 15 \\
& $\quad$ Lime & 3296 & 30 \\
& $\quad$ Mineral Wood & 3292 & 62 \\
250 & 118,652 & Asbestos & 2541 & 40 \\
210 & 15,219 & Tobacco Manufacturers & 2141 & \\
310 & 7,187 & Leather and Leather Products & & \\
\hline
\end{tabular}




\section{SUMMARY AND CONCLUSIONS}

There is a great deal of conjecture on the impetus for US firms to move to Mexico now that NAFTA has come into effect. NAFTA supporters argue that US and Mexican relative factor endowments will be utilized more effectively under the arrangement, thereby increasing the welfare of all parties involved. Detractors of NAFTA argue that utilization of Mexico's relative factor endowments rely on abuses of the environment and the worker.

In spite of the interest and discussion on this matter, there has been little empirical evidence testing the arguments. We found that, contrary to arguments offered by environmentalists, industries moving to Mexico are not doing so to avoid higher US environmental standards compliance costs. We were unable to confirm the position that highly skilled jobs will move to Mexico to take advantage of unfairly suppressed union wages, or the assertion that only low skilled jobs will be shifted to Mexico.

But, rather, it appears that there may be elements of truth to both of these arguments. With respect to ecological issues, we find danger in diametrically opposed views. At first glance, such notions appear justifiable given historic and current conditions, but articulating conflicts in the business-natural environment arena may exacerbate the problem. High environmental standards are not synonymous with high environmental costs. For further study, it would be worth investigating not what the absolute cost differences are between Mexico and the US based on current environmental regulations, but the per-unit relative costs. That is, comparing costs on a standard measure. Breaking down the component costs of environmental compliance in the two countries could prove to be a more useful comparison than weighing noncompliance costs in Mexico with compliance costs in the US. 
Ray (1995) provided accumulated evidence to suggest that US protectionism in recent decades has provided relief to domestic firms in those industries facing substantial pollution abatement costs. He observed that "inefficient domestic producers were nurtured" while “developing country polluters were encouraged to produce dirty industry manufactures for export to the United States" (Ray, 1995: 489). He concluded that both of these groups availed themselves of greater benefits to the detriment of more efficient and possibly even more ecologically benign competitors in other nations. Baumol and Oates (1988) indicated that in the absence of offsetting subsidies, such a dichotomy would encourage specialization in polluting industries and would lead to the developing countries becoming repositories of "dirty industries."

Gladwin and Walter (1976) found that MNEs may gain leverage (competitive advantage) over indigenous firms in host nations, particularly as pollution standards tighten. The interaction between national income and trading opportunities affects the level and incidence of world pollution. Lower-income countries acquire a strategic advantage by setting pollution levels in a free trade regime. This increase in income and pollution comes at the expense of developed nations, both in terms of loss of wealth and increased pollution. Because of this advantage, these countries have an "incentive to delay international pollution negotiations until after multilateral trade liberalization has been achieved" (Copeland and Taylor, 1995: 734). Cairncross (1995) berated the economics profession and reminds us that natural constraints on growth were espoused by both Malthus and Ricardo.

Our understanding of labor issues has reached no more clarity than that regarding environmental issues. There exist systemic differences in the approach that US MNEs take in dealing with 
labor in Mexico. This indicates that labor issues outside of wages (e.g., unionization, employee attitudes, work structure, etc.) may be causal factors in the FDI location decision. It is inconclusive whether or not markets with lower labor standards benefit from or attract investment due to these lower standards (Martin, 1993). Further, "countries see labor regulation as a sovereignty issue and balk at attempts to mandate how they regulate on such issues" (Martin, 1993: 190).

One firm may face rising environmental compliance or labor costs while another may gain advantage under the same conditions. Public policy is an area characterized by a multitude of positions. Mills and Graves (1986: 85) found that "although people make plenty of mistakes in pursuing their self-interest, there is no reason to believe governments make fewer mistakes on behalf of constituents." It follows, therefore, that at a minimum the government ought to pass along insights and better inform its constituents. Schumpeter (1949: 346) found that scientific inquiry "does not require us to divest ourselves of our value judgments or to renounce the calling of an advocate of some particular interest." Neutrality may even be undesirable: "though we proceed slowly because of our ideologies, we might not proceed at all without them" (Schumpeter, 1949: 359).

Charnovitz (1994: 39) observed that "as NAFTA is breaking down the commercial walls between countries, it is also breaking down the intellectual (and professional) walls" among those with disparate assessments of NAFTA. As local issues become global concerns it is no less easy to amass all relevant information, let alone sort through it. While communication is quicker and more complete than ever, attention spans and interest levels are declining despite heightened awareness. These concerns may sound like modern problems of progress, but Roosevelt (1934: 180-181), in the essay, The Man with the Muck-Rake, observed 
that painting rascals in black and white induces a "color-blindness" where citizens believe "neither in the truth of the attack, nor in the honesty of the man who is attacked; they grow as suspicious of the accusation as of the offense."

While it may seem overtly zealous to demand that a trade pact rectify vast imbalances in nature and society, ideologies aside, it seems reasonable to expect such a pact to instill no incentive for harm. The issues raised in this article concerning the location of FDI will continue to be important in the context of trade liberalization as nation states become increasingly interrelated through processes of globalization.

\section{REFERENCES}

Baldwin, R. E. (1971) Determinants of the Commodity Structure of US Trade. American Economic Review 61(1): 126-146.

Baumol, W. J. and Oates, W. E. (1988) The Theory of Environmental Policy. Cambridge, England: Cambridge University Press.

Birdsall, N. and Wheeler, D. Low, P. (ed) (1992) Trade Policy and Industrial Pollution in Latin America: Where Are the Pollution Havens? International Trade and the Environment, pp. 159-167. Washington, DC: World Bank.

Cairncross, F. (1995) Green, Inc.: A Guide to Business and the Environment. Washington, DC: Island Press.

Campbell, D. (1994) Foreign Investment, Labour Immobility and the Quality of Employment. International Labour Review 133(2): 185-204.

Charnovitz, S. (1994) NAFTA's Social Dimension: Lessons from the Past and Framework for the Future. International Trade Journal 8(1): 39-72.

Chichilnisky, G. (1994) North-South Trade and the Global Environment. American Economic Review 84(4): 851-874.

Cohen, J. A. (1993) Productivity: A Jump Start to Better Wages. Business Mexico June: 7-8

Congressional Research Service (1992) Review of US-Mexico Environmental Issues. Pollution Haven Analysis. Washington, DC: Library of Congress.

Copeland, B. R. and Taylor, M. S. (1995) Trade and Transboundary Pollution. American Economic Review 85(4): 716-737.

Ensign, P. C. (2003) The Impact of the North American Free Trade Agreement on the Women of the United States, Canada, and Mexico. International Journal of Commerce \& Management 13(2): 1-28.

Friedman, J., Gerlowski, D. A., and Silberman, J. (1992) What Attracts Foreign Multinational Corporations? Evidence from Branch Plant Location in the United States. Journal of Regional Science 32(4): 403-418. 
Friedman, M. (1962) Capitalism and Freedom: A Leading Economist's View of the Proper Role of Competitive Capitalism. Chicago, IL: University of Chicago Press.

Gladwin, T. N. and Walter, I. (1976) Multinational Enterprise, Social Responsiveness, and Pollution Control. Journal of International Business Studies 7(2): 57-74.

Globerman, S. Anderson, T. L. (ed) (1993) The Environmental Impacts of Trade Liberalization. NAFTA and the Environment, pp. 27-44. San Francisco, CA: Pacific Research Institute for Public Policy.

Harvey, M. G. and Rothe, J. T. (1995) Environet: Monitoring MNCs Global Environmental Behavior. Business \& the Contemporary World 7(4): 114-133.

Hettige, H., Lucas, R., and Wheeler, D. (1992) The Toxic Intensity of Industrial Production: Global Patterns, Trends, and Trade Policy. American Economic Review 82(2): 478-481.

Jaffe, A. B., Peterson, S. R., Portney, P. R. and Stavins, R. N. (1995) Environmental Regulation and the Competitiveness of US Manufacturing: What Does the Evidence Tell Us? Journal of Economic Literature 33(1): 132-163.

Kalt, J. P., Spence, A. M., and Hazard, H. A. (eds) (1988) The Impact of Domestic Environmental Regulatory Policies on US International Competitiveness. International Competitiveness. Cambridge, MA: Ballinger Publishing.

Krugman, P. (1993) The Uncomfortable Truth About NAFTA: It's Foreign Policy, Stupid. Foreign Affairs 72(5): 13-19.

Levinson, A. (1996) Environmental Regulations and Manufacturers' Location Choices: Evidence from the Census of Manufactures. Journal of Public Economics 62(1/2): 5-29.

Martin, C. J. (1994) The NAFTA Debate: Are Concerns About US Job Migration to Mexico Legitimate? Employee Relations Law Journal 19(3): 239-250.

Martin, K. Bognanno, M. F., and Ready, K. J. (eds) (1993) The North American Free Trade Agreement Negotiations and the Canada-US Free Trade Agreement: Revisiting Unfinished Business. The North American Free Trade Agreement: Labor, Industry, and Government Perspectives, pp. 180-193. Westport, CT: Praeger.

Mills, E. S. and Graves, P. E. (1986) The Economics of Environmental Quality, 2nd edition. New York, NY: W. W. Norton.

Naisbitt, J. (1994) Global Paradox: The Bigger the World Economy, the More Powerful Its Smallest Players. New York, NY: William Morrow and Company.

Penrose, E. T. (1995) The Theory of the Growth of the Firm, 3rd edition, Oxford, UK: Oxford University Press.

Porter, M. E. and van der Linde, C. (1995) Toward a New Conception of the EnvironmentCompetitiveness Relationship. Journal of Economic Perspectives 9(4): 97-118.

Post, J. E. (1991) Managing as If the Earth Mattered. Business Horizons 34(4): 32-38.

Ray, E. J. (1995) Global Pollution Effects of US Protectionism. International Trade Journal 9(4): 475-493.

Roosevelt, T. (1934) Roosevelt's Writings. New York, NY: Macmillan.

Schumpeter, J. A. (1949) Science and Ideology_-Presidential Address Delivered to the 61st Annual Meeting of the AEA, Cleveland, Ohio, December 28, 1948. American Economic Review 39(2): 345-359.

Seldon, T. and Song, D. (1994) Environmental Quality and Development: Is There a Kuznets Curve for Air Pollution Emissions? Journal of Environmental Economics and Management 27(2): 147-162. 
Tucker, M. T. (1995) Pollution Prevention: Economically Viable Environmental Protection. Business \& the Contemporary World 7(3): 52-61.

US Congress, Office of Technology Assessment (October 1992) US-Mexico Trade: Pulling Together or Pulling Apart? ITE-545. Washington, DC: US Government Printing Office.

Wood, A. (1994) North-South Trade, Employment and Inequality: Changing Fortunes in a SkillDriven World. Oxford, England: Clarendon Press.

Wright, H. K. (1971) Foreign Enterprise in Mexico: Laws and Policies. Chapel Hill, NC: University of North Carolina Press.

\section{DATA SOURCES}

US Department of Commerce, Bureau of Economic Analysis. US Direct Investment AbroadBalance of Payments and Direct Investment Position Estimates 1989-1993. IID (BE-50). Washington, DC.

US Department of Commerce, Economics and Statistics Administration, Bureau of the Census. Statistics for Industry Groups and Industries. Annual Survey of Manufacturers.

US Department of Commerce, Economics and Statistics Administration, Bureau of the Census. US Merchandise Export Trade, Country by Industry-Exports to Mexico. National Trade Data Bank.

US Department of Commerce, Economics and Statistics Administration. US Merchandise Import Trade, Country by Industry_-Imports from Mexico. National Trade Data Bank.

US Department of Commerce, Economics and Statistics Administration, Bureau of the Census. Current Industrial Reports-Pollution Abatement Costs and Expenditures. 